\title{
Identification of hydrovolcanism and its significance for hydrocarbon reservoir assessment: A review
}

\author{
Ben-Zhong Xian ${ }^{1,2^{*}}$, Yan-Xin He ${ }^{1}$, Hua-Peng Niu ${ }^{1,2}$, Jun-Hui Wang ${ }^{1,2}$, Jian-Ping Liu' and Zhen Wang ${ }^{1}$
}

\begin{abstract}
Investigations of modern volcanic eruptions have demonstrated that ancient volcanic eruptions widely involved water, which was thus named as hydrovolcanic eruptions. Hydrovolcanisms are distinctive in many aspects, such as dynamics, eruptive pattern, texture and structure of rock, and vesicularity. First, normal sediments covered directly by volcanic rocks are the indicators of eruption environments. In addition, microfeatures, special structures, lithofacies or facies associations, and geochemical index of volcanic rocks can also provide significant evidences. Moreover, perlitic texture, quenching fragmentation, surface feature, cementation type, vesicularity, and pillow structure, parallel bedding, large-scale low-angle cross-bedding, antidune cross-bedding of pyroclast are keys to indicating hydrovolcanisms. Clearly, these marks are not equally reliable for identifying eruption environments, and most of them are effective and convincible in limited applications only. For explosive eruptions, the most dependable identification marks include quenching textures, vesicularity in pyroclasts and special large-scale cross-bedding. However, for effusive eruptions, useful indicators mainly include pillow structure, peperite and facies associations. Condensation rate of magma, exsolution of volatile affected by eruptive settings and magma-water interaction, and quenching in hydrovolcanisms have an influence on formation and scale of primary pores, fractures and their evolution during diagenetic stage. Therefore, this review provides systematic identification marks for ancient hydrovolcanisms, and promotes understanding of the influence of eruptive environments on hydrocarbon reservoirs of volcanic rocks in oil-gas bearing sedimentary basins.
\end{abstract}

Keywords: Hydrovolcanism, Volcanic reservoir, Eruption environment, Hydrocarbon reservoir, Oil-gas bearing sedimentary basin

\section{Introduction}

Hydrovolcanism is the term that describes the interaction between meteoric or connate water and lava, magmatic heat, or gases at or near the Earth's surface, and it encompasses the physical and chemical dynamics that determine the resulting intrusive or extrusive behavior and the character of eruptive products and deposits (Valentine and Fisher 1999; Wohletz et al. 2013). Hydrovolcanisms contain subaqueous eruptions and subaerial eruptions involved with water. The statistical results indicate that subaqueous volcanic eruptions on

\footnotetext{
* Correspondence: xianbzh@163.com

${ }^{1}$ College of Geosciences, China University of Petroleum (Beijing), Beijing 102249, China

${ }^{2}$ State Key Laboratory of Petroleum Resources and Prospecting, China University of Petroleum (Beijing), Beijing 102249, China
}

the Earth account for $85 \%$ of the global volcanic eruptions, approximately $3.485 \mathrm{~km}^{3} / \mathrm{yr}$. and well above subaerial eruptions (White et al. 2003), which demonstrate that hydrovolcanisms widely exist in volcanic eruptions. However, due to the difficulty of field monitoring and the high cost of submarine sampling, current research degree of eruption process and petrological characteristics of hydrovolcanisms is still lower (Carey 2000; White et al. 2003).

The water involved in a hydrovolcanism can come from ground water, connate water, marine, fluvial or lacustrine water, glacier and rain water (Wohletz et al. 2013). Research on the round crater lake of Quaternary volcanic field in Eifel, western Germany (named "maar" at the time) sets the work on hydrovolcanism (phreatomagmatic eruption) since 1983 (Fisher et al. 1983). 
People come to realize that the involvement of water, which is completely different with air in physical properties, changes the dynamic condition and eruption style of volcanic eruptions, as well as the process of dispersion, transportation and sedimentation of eruption products (Cas and Giordano 2014; Dziak et al. 2015), and leads to the specificity in such factors as grain size distribution, fragmentation, rock texture, sedimentary structure and vesicle abundance (Sun and Fan 2005).

In addition to a large number of submarine volcanic eruptions, the case studies on eruptions that occurred under lacustrine, for example, indicated by phenomenon and data from Karymskoye Lake in Russian (Belousov and Belousova 2001), famous Taupo Volcano in New Zealand (Manville et al. 2009), Sirinia Basin in Southwest Romanian-Eastern Europe (Seghedi 2011) and Tocomar Volcano in Argentina (Petrinovic and Colombo Piñol 2006), etc. have demonstrated the occurrence of hydrovolcanisms in lakes (Stix 1991; White et al. 2003; White et al. 2015). Lava and pyroclastic rocks have been found generally developed along with hydrovolcanism when investigating the Paleogene of the Jianghan Basin (Run et al. 1996), the Yingcheng Formation of the Songliao Basin (Zhang et al. 2007), the Carboniferous of the Santanghu Basin (Wang et al. 2010) and the Carboniferous of the Junggar Basin (Yu et al. 2004). The physical properties of water in density, viscosity (rheology), heat capacity, thermal conductivity and phase state are significantly correlated with the peculiarity of hydrovolcanism. For instance, magma-water interaction will lead to water vaporization, quenching and vapor explosion, fragmentation, etc., and then lead to differences in eruption process and volcanic product features (White et al. 2003), further affecting the characteristics of pores or fractures and the quality of reservoirs in the hydrovolcanism.

Petroleum exploration history of more than 120 years with volcanic rocks in the world reveals that considerable petroliferous sedimentary basins contain volcanic facies of different sizes (Zou et al. 2008). The prospecting of the 11 Chinese basins, such as Bohai Bay Basin, Songliao Basin (Wang et al. 2003a, 2003b), Junggar Basin (Kuang et al. 2008) and Santanghu Basin (Zhao et al. 2006), demonstrated that the prediction of highquality volcanic reservoirs is the key to successful explorations (Wang et al. 2003a, 2003b; Zou et al. 2008; Xian et al. 2013). Recent investigations demonstrated that the performance of reservoir was controlled by diagenesis (including epigenetic weathering), volcanism and tectonic activity (Chen et al. 2003; Wang et al. 2003a, 2003b; Dong et al. 2012), as well as volcanic eruption environment (Xian et al. 2013). To date, effective identification of the ancient volcanic eruptions still has not followed the technological advance in volcanic reservoirs based on the eruption environment. In this paper, we systematically summarize the identification marks of hydrovolcanism and discuss their limits and reliability based on depositional environment and volcanic eruption products, in order to provide identification marks for ancient volcanic eruptions, increase the understanding of hydrocarbon reservoirs of hydrovolcanisms, and offer new ideas for volcanic reservoir evaluation.

\section{Identification marks of hydrovolcanism}

There are subaerial eruption and subaqueous eruption as types of volcanic eruption according to their different geographical environments. The eruption environment, however, is not exactly equivalent to the depositional environment. Products of subaerial eruption can deposit on land as well as under water; similarly, the products of subaqueous eruption can also deposit both on land and under water. The hydrovolcanism discussed here emphasizes the volcanic eruption which has high interaction with the water, and is approximately the same as phreatomagmatic eruption, including subaqueous eruption and subaerial eruption involved with water.

The identification marks of the subaqueous volcanic eruption will be described in detail in terms of the characteristics of the eruptive products (Section 3) and the associated depositional environment records (Section 4) of the volcanic rocks.

\section{Characteristics of the eruptive products}

Eruptive process is influenced by magma composition, explosive degree, transportation and deposition. Such characteristics as the microtextures, special structures, lithofacies or facies sequences and oxidation index of eruptive products (volcanic rocks) can reflect these processes. In turn, these characteristics of the volcanic rocks can be used to infer the type and process of eruption, and further identify the eruption environment (Table 1).

\subsection{Microtextures}

Microtextures of eruptive products provide a wealth of information for researching physical and chemical properties of magma, and features of eruptive processes and subsequent diagenesis. The following five microtextures are discussed for identifying hydrovolcanism (Table 1).

\subsubsection{Perlitic texture}

Perlite is a kind of acidic lava commonly developed when acidic lava has interacted with water, the moisture content of which is $2 \%-6 \%$. Perlitic texture, an arc-shaped fissure texture looking like pearl, which is a typical texture of perlite, indicates that it may be formed in a violent quenching process (Fig. 1a). However, perlitic texture and perlite could also appear in intrusive facies and extrusive facies which do not indicate depositional environment. Therefore, generally, perlitic texture and perlite formed 


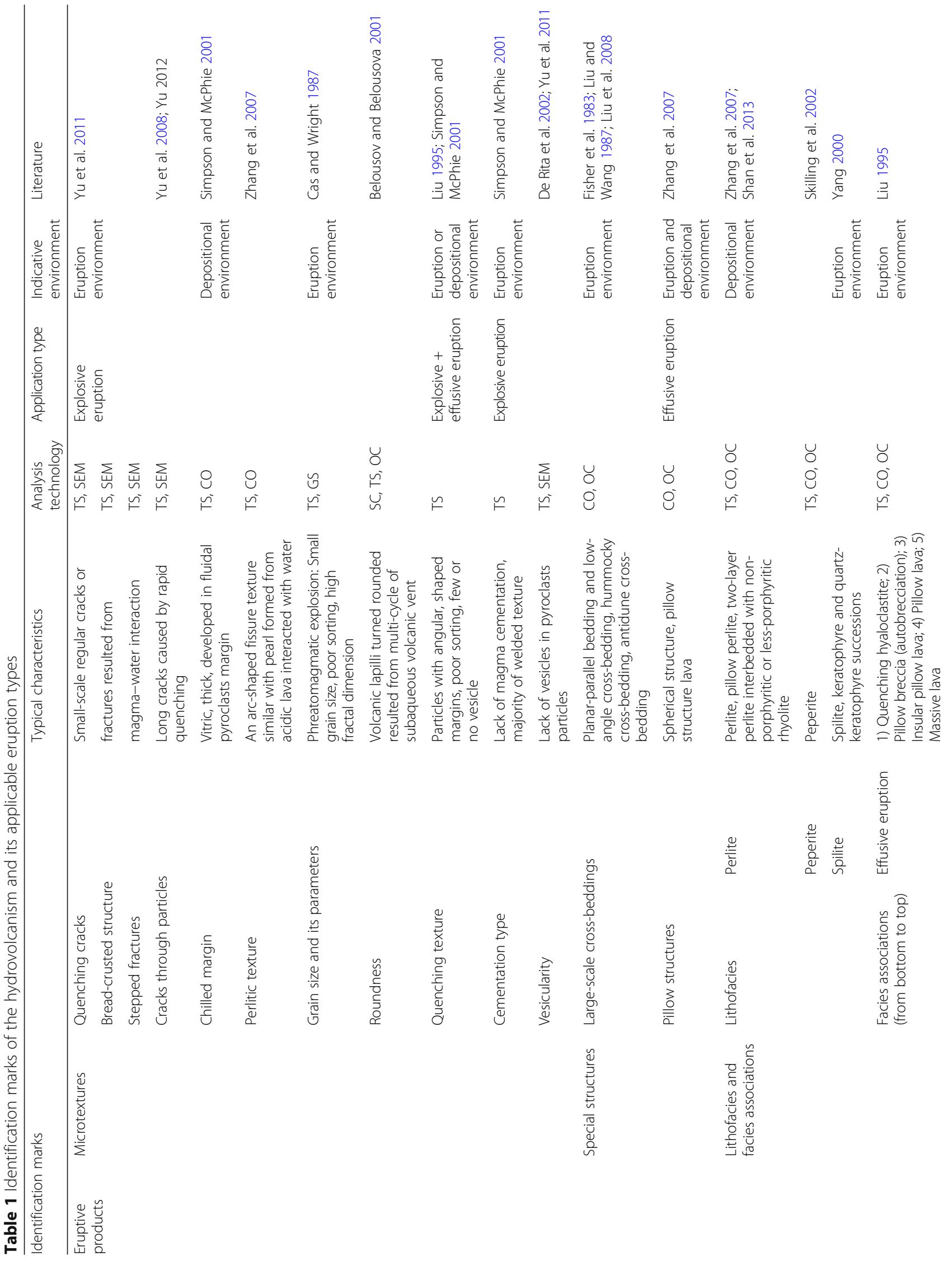




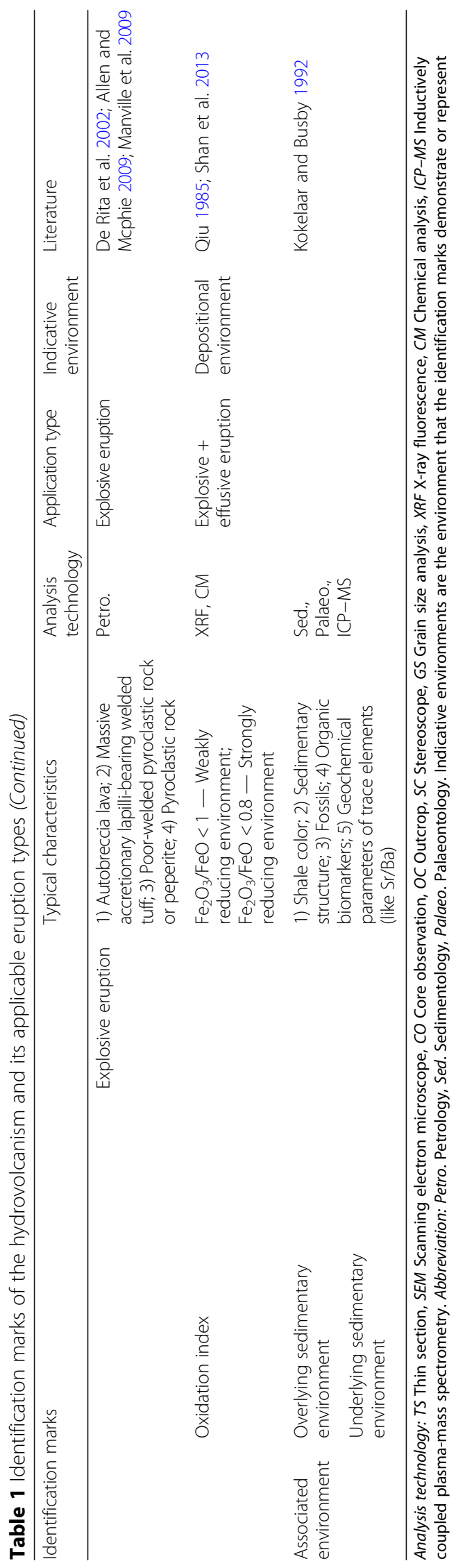



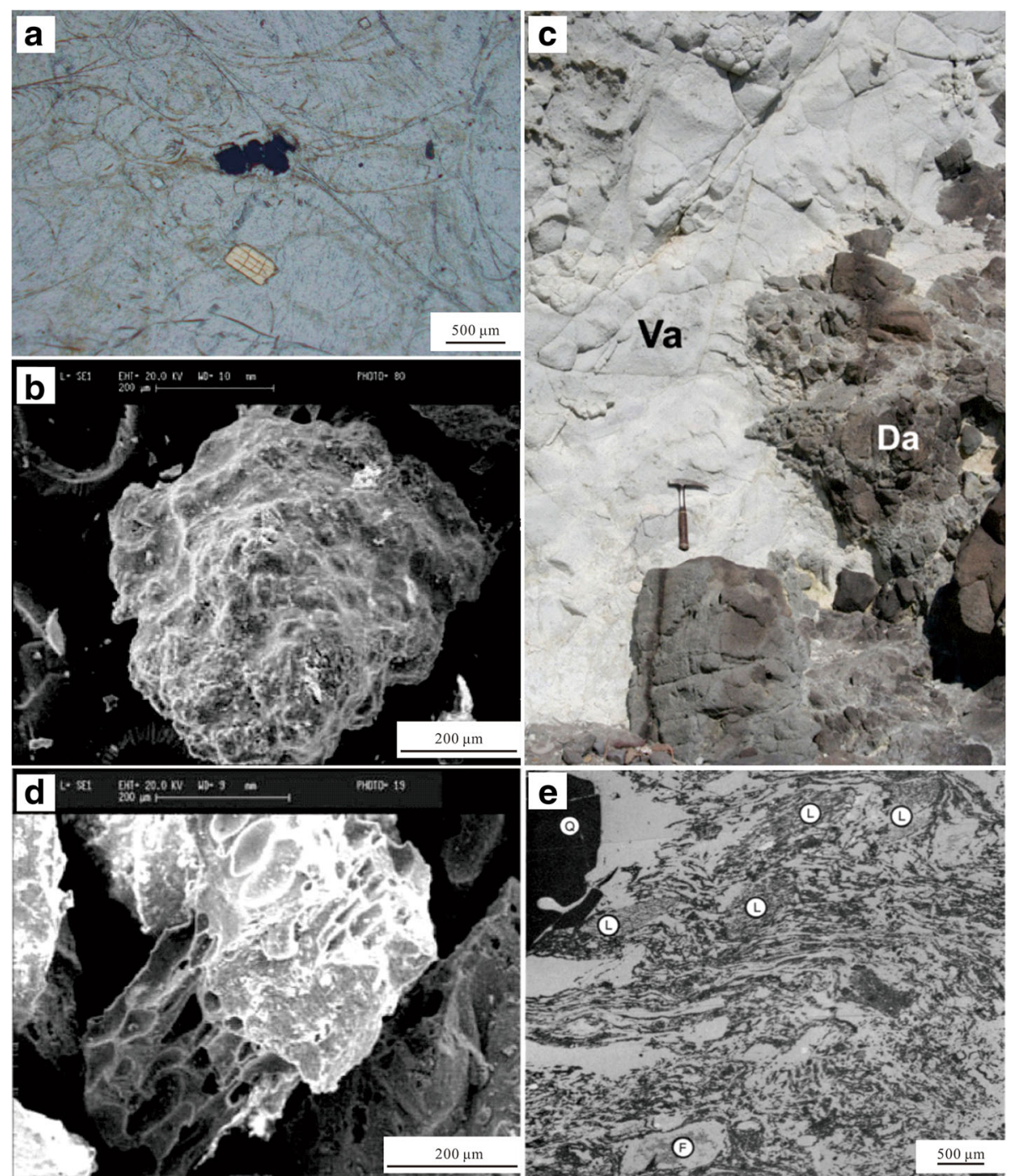

Fig. 1 Texture characteristics of volcanic rocks applied to identify hydrovolcanism. a Perlitic texture and porphyritic texture (cross-polarized light), the Yingcheng Formation in the Santai Area, Songliao Basin (Shan et al. 2007); b Bread-crusted structure in pyroclasts particles (Sample JY-11-05, SEM), Quaternary, the Nanlongwan Volcano, Jilin Province (Yu 2012); c Contact relationship between lapilli-bearing quenching hyaloclastite and vesicular clasts (Soriano et al. 2013); d Blocky volcanic scoria with well-developed tube-shaped vesicle (Sample JY-11-05, SEM), Quaternary, the Nanlongwan Volcano, Jilin Province (Yu 2012); e Back-scattered electron image of welded Vandever Mountain tuff formed from subaqueous explosive eruption. Q-Quartz crystals (black); F-Feldspar crystals; L-Lithic fragments (Kokelaar and Busby 1992)

from subaqueous effusive eruption are interpreted as the result of a hydrovolcanism in which the eruptive vent is close to the depositional environment (Shan et al. 2007, 2013; Zhang et al. 2007).

\subsubsection{Quenching texture and superficial features}

Quenching is the process of superficial stripping and granulation of lava and early fragments resulted from cooling and contraction caused by the interaction between hot magmatic melt and cooled water or hydrated deposits (Cas and Wright 1987). Hyaloclastite, a kind of pyroclastic rock formed by quenching, has a quenching texture, completely different from the explosive volcanic pyroclasts with arc polygon, smooth concavity and convexity, and vesicles. Quenching texture is characterized by a polygonal shape, sharp margin (bladed margin) angles, linear or tabular edge, and concentric or radiated cooling joint with multiple cracks.

The high heat capacity of the water leads to rapid cooling of magma and hot rocks, and generates chilled margins, quenching fragments and other special morphology features in particle surfaces such as quenching crack and fracture (Yu et al. 2011). The formation of cracks through particles and explosive fissures in phenocryst generated in the pyroclastics may be related to the rapid cooling. Additionally, the bread-crusted structures 
(Fig. 1b) and cauliflower-shaped surfaces are the result of quenching fragmentation when hot pyroclastics are interacted with cooled water. This interaction also produces brittle breaks and stepped fractures after cooling. These microtextures of quenching cracks, bread-crusted structures, cauliflower-shaped surfaces and irregular fractures of the Quaternary Nanlongwan volcano in Jilin Province can indicate that there may have been phreatomagmatic eruption with water involved.

Effusive eruption occurs when the magma flows into the water or deep water; meanwhile, the outer part of lava flow undergoes the quick cooling and quenching, while the inner part continues moving. The outer will quickly solidify and generate a chilled margin and may further produce debris, fragments, or fissures by brittle cracking, forming autobreccia and pillow breccia, which are the result of autobrecciation commonly developed at the margin of or between the lava flows (Fig. 1c). The autobrecciation and quenching fragmentation often occur simultaneously, yielding a thick sequence of pyroclastics rocks. Field geological studies on the Late Jurassic rhyolitic quenching pyroclastic rocks (Xia 1999) and the Early Cretaceous basaltic quenching pyroclastic rocks in northern Hebei Province (Xia 1993), verified that quenching can occur in various magmas ranging from the basaltic lava to the acidic lava, and its products including quenching pyroclastic agglomerate, quenching pyroclastic breccia and quenching tuff, are diverse.

Quenching usually occurs in the following three situations: (1) underwater volcanic (explosive or effusive) eruptions; (2) lava flow or hot pyroclastic flow entering in a kind of water-bearing environment; or, (3) magma intruding into unconsolidated hydrated sediments. Obviously, formation of the quenching texture and its associated structures has strong correlations with water, for example, quenching texture can be caused by phreatomagmatic eruption, either subaqueous eruption or subaerial eruption, in a littoral environment with abundant underground water. Therefore, it's essential to consider these textures along with other markers when identifying the eruption environment.

Büttner et al. (1999) took the experimental equipment TEE-II to remelt the scoriae of La Sommata volcanic cone from the La Fossa Volcano, and then injected $500 \mathrm{~cm}^{3}$ water into $0.4 \mathrm{~kg}$ remelted magma to generate a violent magma-water interaction and an explosive eruption. The surfaces of the products of this simulated experiment are developed with branched quenching cracks (Fig. 2a), virtually identical to the surge deposits (Fig. 2b) of phreatomagmatic eruption in the La Fossa Volcano (Büttner et al. 1999). Büttner et al. (2002) also remelted the shoshonitic rocks from the La Fossa di Vulcano Volcano, and then did the Molten Fuel Coolant Interaction (MFCI) experiment and got the products with subrounded shape or Pele's hairs, rough surface, fractures and quenching cracks (Fig. 2c), almost the same as the base sediments of the Palizzi area in grain shape and surface morphology (Fig. 2d) (Büttner et al. 2002).

\subsubsection{Grain size distribution and its parameters of pyroclasts}

The high density and high viscosity of water will reduce the falling of the pyroclast velocity, weak the movement or expansion of the eruption column or density flow, and increase buoyancy. Therefore, hydrovolcanic pyroclasts near crater are better rounded and better sorted than other pyroclasts (White et al. 2003). The fine roundness of the grains, especially those lapilli, may benefit from the multiple-phase circulation near crater because the water layer at the top crater prevents pyroclasts from being ejected by explosion (Belousov and Belousova 2001).

In terms of grain size analysis, Walker (1971) established the distinguishing charts of genetic types of pyroclastic accumulations, which generally reflected that the grain size is related to the explosion degree of volcanic eruption. For the explosion degree of phreatic eruption, phreatomagmatic eruption and magmatic eruption, the first is the most intensive one while the third is the least. Based on the median size, sorting coefficient, skewness, peakedness and their interrelation, these charts are widely used in the semi-quantitative reconstruction of transport processes of fallout, surge and pyroclastic flow (Cas and Wright 1987).

\subsubsection{Characteristics of vesicles in pyroclasts}

The content of volatiles in magma controls the degree of vesicle development in volcanic rocks, and greatly affects the type of volcanic eruption (explosion or effusion). However, numerous studies on phreatic eruption and phreatomagmatic eruption have demonstrated that the vaporization of hot magma interacted with the surface water or ground water can also provide energy for the volcanic eruption and change the style of volcanic eruption.

Regarding the explosive eruption, pyroclasts with high vesicle contents (Fig. 1d) usually show that the magma containing abundant volatiles undergoes strong exsolution, and the energy of the volcanic eruption is the result of the large gas expansion. Similarly, pyroclasts (e.g., lapilli) with few vesicles (Fig. 1b) indicate low volatiles content, which means the energy for explosive eruption may be derived from the vaporization of hot magma interacted with the surface water except from exsolution of volatiles content (De Rita et al. 2002). Therefore, the vesicle contents of pyroclasts (lapilli) can be used to identify hydrovolcanism if it is confirmed as the explosive eruption. A lack of vesicles in pyroclasts indicates that part of the energy is derived from the rapid vaporization 

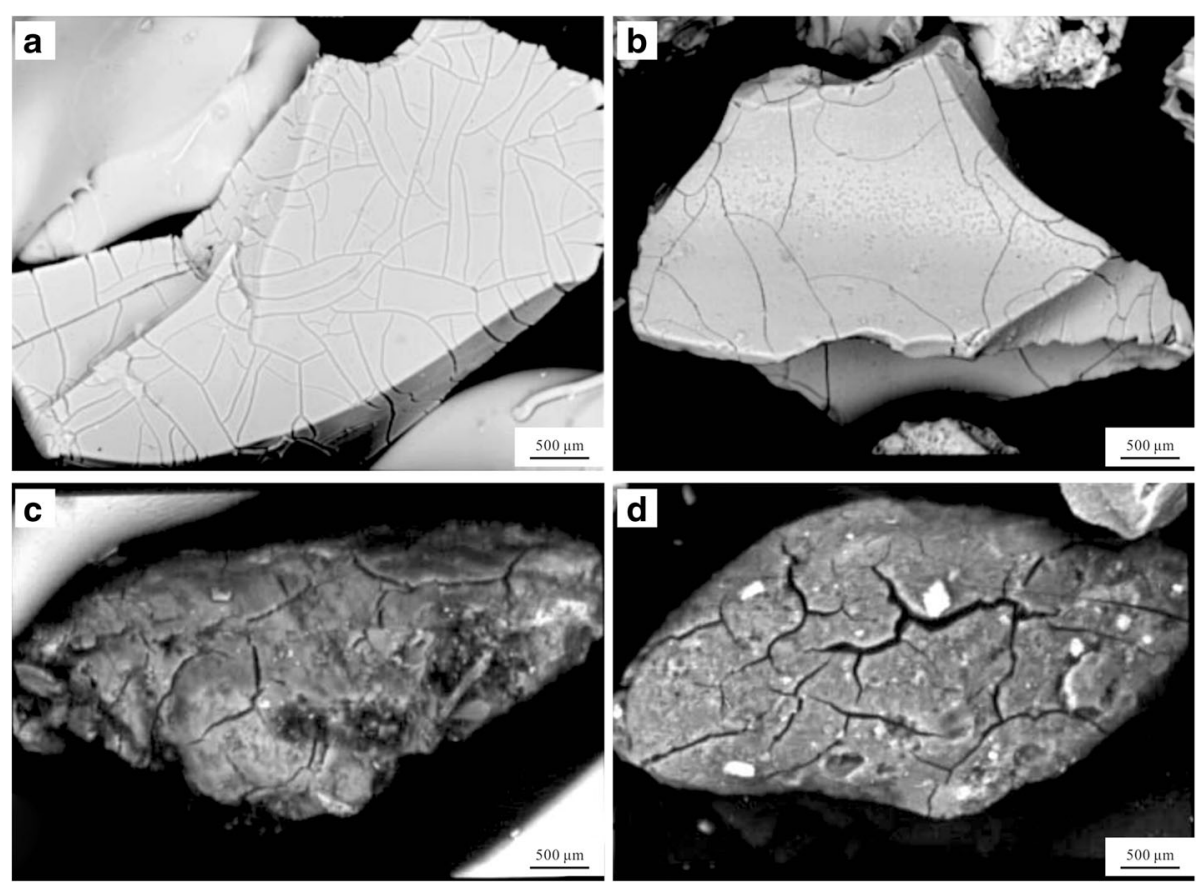

Fig. 2 Microtexture characteristics (SEM) of eruptive products formed by magma-slurry experiments and hydrovolcanism. a Experimental products formed by magma-water interaction showing quenching cracks (Büttner et al. 1999); b Analogue particle from a "wet" phreatomagmatic surge deposit of the La Fossa Volcano (Büttner et al. 1999); c Subrounded particle produced by the Molten Fuel Coolant Interaction experiment showing quenching cracks formed by the contact between hot fragments and liquid water (Büttner et al. 2002); d Surge deposit of the La Fossa Volcano of Palizzi area showing quenching cracks formed by the contact between hot fragments and liquid water (Büttner et al. 2002)

of hot water when the magma interacts with the surface water during the hydrovolcanism. Previous studies have demonstrated that, at sea floor less than $3 \mathrm{~km}$ deep, the vapor generated by the interaction between magma or hot particles and water may cause intense expansion, even explosion (White et al. 2003).

\subsubsection{Cementation type}

With the increase of water depth, the huge static pressure in deep water area will inhibit the expansion of boiling water vapor and magmatic gas, weaken the degree of explosion, and condense the gas at the eruption column, which resulted in the no-magmatic cementation in volcanic scoria and plastic pyroclasts. Pyroclastics or welded pyroclastics (Fig. 1e) rather than lava are developed because of lacking welding or magma cementation. Therefore, the cementation type of pyroclastics is indicative to the eruption environment. For example, the fluidal-clastic breccia of Australian basaltic andesite is interpreted as the important evidence of submarine eruption (Simpson and McPhie 2001).

It has to be noted that such factors as the margin shape, surface texture, grain size distribution, sorting and vesicle abundance of pyroclasts are intrinsically consistent in reflecting eruption environment and process. To increase the accuracy in identifying the eruption environment, it is vital to consider researches comprehensively such as the origin of Agnano-Monte pyroclasts in southern Italy (Dellino et al. 2001) and the phreatomagmatic eruption of the Quaternary volcanism in the Longgang Volcano Group, northeastern China (Bai et al. 2004).

\subsection{Special structures}

\subsubsection{Pillow structure and spherical structure}

Pillow structure, an acknowledged primary structure, is usually formed in the hydrovolcanism process of basaltic lava. Quenching between the hot lava and the water will solidify in ellipsoidal-shaped, bread-shaped, pillow-shaped or spherical-shaped, and then form pillow or spherical body. Individual or connected pillows or spherical bodies are cemented by sediments, volcanic and vitric materials (Fig. 3a). Therefore, the pillow structure is composed of vitreous chilled margins, and develops concentric or radial vesicle, inner cavity or radial joints, which are different from the spherical weathering.

Though most common in the ocean, pillow structure can also be distinguished in rivers, lakes, and other wet environments as well. By considering the effect of water pressure on the volatile exsolution, the pore content can be used to roughly estimate the water depth of the lava flow. Generally, the water depth is approximately $1000 \mathrm{~m}$ 

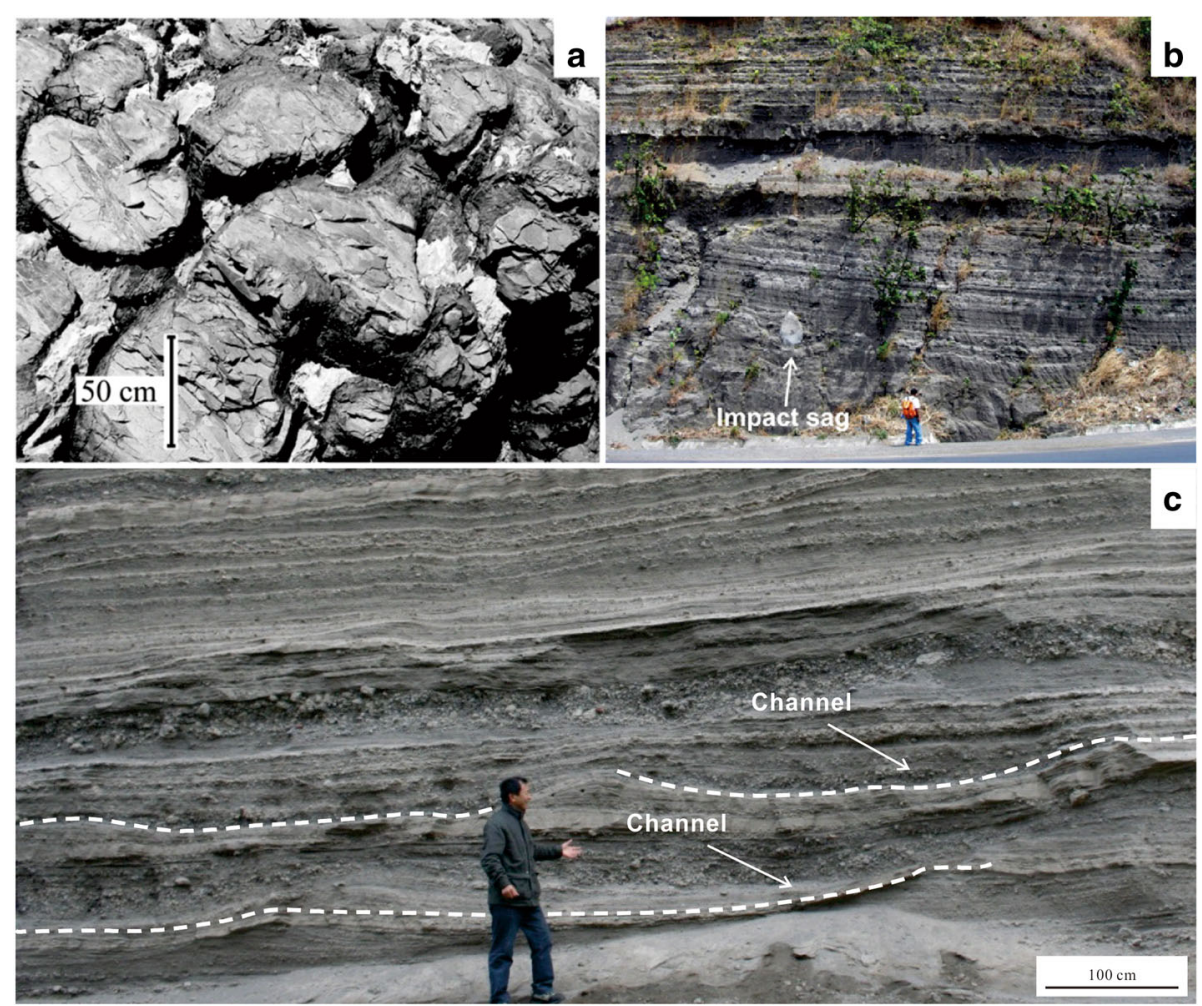

Fig. 3 Special structures formed by hydrovolcanism. a Basaltic pillow lava (Caroff et al. 2009); b Pyroclastic base surge deposits at Cuesta del Plomo inferred from large-scale low-angle cross-beddings and/or planar-parallel beddings, and impact sags (Pardo et al. 2008); c Large-scale antidune and plate-shaped scour channels, Laacher See Volcano, Germany (Liu et al. 2008)

when the vesicle content is less than $5 \%$; and, the water depth is less than $500 \mathrm{~m}$ when the vesicle content is $10 \%-40 \%$ (Sang and Ma 2012).

\subsubsection{Large-scale cross-bedding and erosion groove}

According to the eruption environment and the sediment composition, pyroclastic surge includes ash-cloud surge, ground surge and base surge (Fisher et al. 1983; Liu et al. 2008). Among these surges, ash-cloud surge and ground surge (also known as dry surge) developed in the subaerial environment and are accompanied by the pumice flow of magmatic eruption. Ash-cloud surge mainly generates fine volcanic ash, while the ground surge mainly produces coarse and rigid fragments. The term of base surge, also called wet surge, is derived from the description of the underwater thermonuclear experiment of Bikini Atolld, South Pacific in 1947 (Liu et al. 2008). It is a kind of rapidly expanding and low-density gas-solid density flow that represents the water-related volcanism, the phreatomagmatic eruption (Xu et al. 2005), which is formed by the explosion of upward magma interacting with surface water or groundwater.

Diagnostic marks for hydrogenic pyroclastics deposited and transported by the base surge mainly contains ash pellet, accretionary lapilli, and the symbolic structures including like large-scale low-angle tabular cross-beddings, planar parallel beddings, large-scale hummocky crossbeddings, antidune (dune-like) structures, U-shape or $\mathrm{V}$-shape erosion grooves and trough cross-beddings (Fig. 3; Liu et al. 2008). So, large-scale low-angle cross-beddings, parallel beddings, large-scale antidune and scour channels or erosion grooves, etc., can be used as the identification marks of a hydrovolcanism environment (Fig. 3), such as in the base surge deposits of the Dalongwan Volcano in Jilin Province (Liu and Wang 1987; Xu et al. 2005).

Besides the origin of base surge, cross-beddings and dune-like structures can also be developed by wind or water flow. There are several features that allow one to distinguish between these origins or environments: (1) sorting features. Fluvial sands and wind-blown sands are well sorted, but pyroclastic surge deposits show more poorly sorting degree and can carry particles $\geq 10 \mathrm{~cm}$ in proximal localities; (2) bed forms. Unlike ripples and dunes in water- or wind-transported materials, angles of the backset beds of surge dunes are commonly steeper than the foreset beds; (3) overall geometric relationships. For pyroclastic surge deposits, the dune-migration direction and other flow directions will indicate radiating patterns from the vent location. In contrast, the geometry of water-lain deposits will generally be constrained by 
drainage channels or basins; (4) special products. Pyroclastic bed sets are commonly capped by fine-ash fallout layers, often containing accretionary lapilli; (5) plant fragments in modern pyroclastic deposits. Pyroclastic surge will commonly travel over vegetated-forested areas and incorporate plant fragments. An observation of downed tree or charred wood casts in a bedded pyroclastic deposit can be served as a strong indication of surge origin. Note that in ancient deposits, plant fragments may be difficult to be recognized.

\subsection{Volcanic lithofacies and their associations}

Lithofacies and their associations are essential in studying the process of volcanic eruptions. Meanwhile, magmatic properties and eruptive environments can control the processes, lithofacies characteristics and assemblage patterns of volcanic eruptions. Hence, special volcanic lithofacies or facies associations are helpful to recognize the ancient volcanic eruption environment.

\subsubsection{Special lithology and lithofacies}

1) Peperite

Peperite, a special kind of pyroclastic rock, is of great significance for understanding the interaction between magma and water (Skilling et al. 2002), and is generally used as one of the most direct and reliable evidences for the recognition of hydrovolcanisms.

The magma of peperite contains large range of types from basalt to rhyolite, and is characterized by vitreous, aphanitic or porphyritic texture formed by rapid condensation, which is resulted from the magma-water interaction and has been recognized in the Mesozoic volcano-sedimentary basins in eastern Hebei Province (Bai et al. 2004) and western Liaoning Province in China, the Jurassic in southern Chile (Hanson and Wilson 1993), Coombs Hills in Antarctica (McClintock and White 2002), Gulch Volcano of the western Snake River Plain volcanic field, Idaho (Nemeth and White 2009) and Cambrian Mount Read Volcanics in Australia (Gifkins et al. 2002). According to the liquefaction degree of the underlying sediments (Shanmugam 2017), peperite can be divided into fluidal peperite and blocky peperite (Fig. 4; Chen et al. 2013).

On the other side, there are two genetic types of peperite, intrusive-type peperite and effusive-type peperite. The intrusive-type peperite is usually formed by the magma intruding into the near-surface layer or the unconsolidated hydrate sediments, and is generated symmetrically on both sides of the magmatic intrusion. The effusive-type peperite is formed by magma flowing on the surface of hydrate loose sediments which are commonly from subaqueous or subaerial eruptions, and is generated at the bottom and/or the front of lava flows. When magma enters the environment of wet deposits (usually underwater), the lava flow will mix with the moist, loose deposits to form peperite, where the magma fragments are characterized by various sizes of the interconnected-irregular sheets, lobes and folds, and generally showed plastic features (Skilling et al. 2002).

The formation of peperite is closely related to water. However, peperite indicates its depositional environment, rather than the eruption environment.

\section{2) Perlite}

Perlite, named after the perlitic microtexture, is composed of volcanic glass. The formation of perlite is very complicated and may be reasonably related to water content or pressure. In traditional view, perlite is formed by quick chilling when the acidic lava flows into a water-bearing environment; perlite also can be formed when the magma intrudes or extrudes into a relative colder environment. Thus, the origin of perlite is closely related to the magma-water interaction and the occurrence of perlite can indicate the depositional environment and/or the emplacement environment combining with the petrographic analysis (i.e., Shan et al. 2007). The two-layer perlite interbedded with non-porphyritic or less-porphyritic rhyolite and bentonite in the Xujiaweizi Area of the Songliao Basin (i.e., Shan et al. 2013), which were commonly developed in the bottom of the pyroclastic flow subfacies of explosion facies and the intermediate -inner subfacies of extrusive facies, can be used as an identification mark for hydrovolcanism.

\section{3) Spilite, keratophyre and quartz-keratophyre}

Spilite defined by Brongniat in 1827, is one type of basic volcanic rocks containing sodium plagioclase with cryptocrystalline, and is characterized by grayish-green color, sodium-rich but calcium-poor feature, and may usually develops intergranular texture, diabasic texture, tuff texture and pillow structure.

Spilite, keratophyre and quartz-keratophyre are often incorporated into the eruptive succession of submarine volcanoes and form spilite-keratophyre construction which is commonly regarded as a marine volcanic succession and is commonly developed in the orogenic belt as well as around the modern mid-ocean ridge, accompanied with pillow lava and marine sedimentary rocks (Yang 2000). At present, there still exists a controversy regarding the origin of spilite-keratophyre. One possible origin is magmatic crystallization and the opposite one is the epigenetic alteration. Therefore, the spilitekeratophyre construction is only suited for auxiliary reference when it is used for environment identification.

\subsubsection{Lithofacies associations or facies sequences}

The lithofacies change of the volcanic eruption is the response of magma with certain components to the 


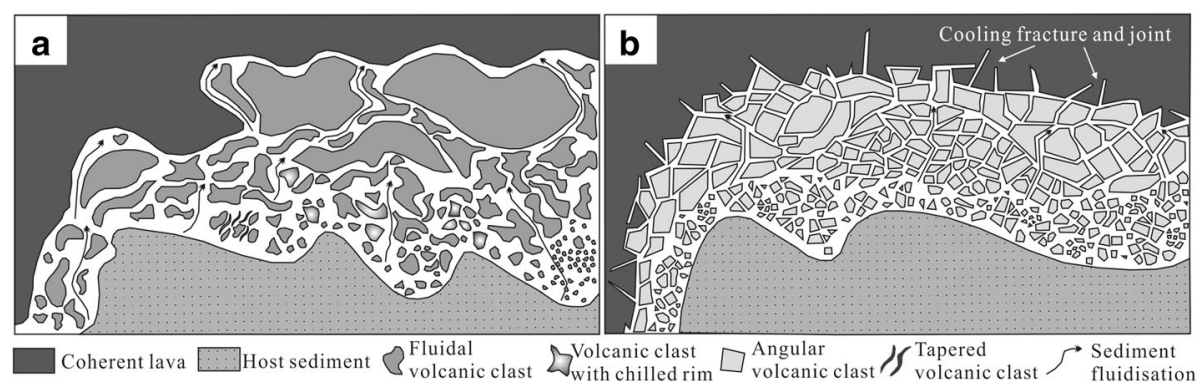

Fig. 4 Simplified schematic diagram showing the formation of $\mathbf{a}$ Fluidal peperite and $\mathbf{b}$ blocky peperite according to the liquefaction degree of its underlying sediments in West Junggar Basin, China (after Chen et al. 2013)

physical and chemical conditions of the volcanic eruption. The characteristics of hydrovolcanism determine the special lithofacies associations and facies sequences.

1) Lithofacies associations of subaqueous effusive eruption

When the magma volatile content is low or the magma is erupted in deep water environment, the volcanic eruption is effusive. As mentioned before, quenching occurs when hot magma reacted with cool water, which will lead to quench fragmentation and autobrecciation. As a result, quenching and its derivatives will produce thick lava-pyroclastics sequences: (1) massive lava; (2) pillow lava; (3) insular pillow lava; (4) pillow breccia; (5) quenching hyaloclastite (Liu et al. 1993). Multiphase subaqueous non-explosive eruption can also occur, generating submarine lava complex, the center of which is crystalline while the margin is vitric with perlitic texture (Liu 1995).

2) Lithofacies associations of subaqueous explosive eruption

Recently, research on subaqueous explosive eruptions has received more attention. Using a few examples, the vertical association model of lithofacies in different eruption conditions is summarized.

The study of phreatomagmatic eruption in the Colon Albani Volcano, Italy, revealed a high energy explosive eruption model of lithofacies associations in shallow lake environment. From bottom to top, the products of a single basic magmatic exhalation generally contain: (1) phreatoplinian fallout, air fall; (2) base surge, dilute pyroclastic flow or surge pyroclastic flow deposits, layered or cross-bedding (weak welded) pyroclastic deposits; (3) pyroclastic flow deposits, large-scale accretionary lapilli-bearing welded tuff; (4) auto-breccia and lava flow deposits, dominated plastic fragment (De Rita et al. 2002).

Manville et al. (2009) integrated the terms of pyroclastics and proposed a facies sequence model of hydrovolcanism equipped with facies sequence composition according to depositional process and eruption orders, including five units from bottom to top: (1) tephra fall; (2) pyroclastic surge; (3) gas-supported pyroclastic flow; (4) lava with stream gravel; and, (5) block and ash flow (Manville et al. 2009).

In addition, Allen and McPhie (2009) proposed a new facies sequence model for the Neptunian eruption in large water depths (200-1300 m) with abundant pumices and accretionary lapilli, including three units from bottom to top: (1) Neptunian lithic breccia, the fallout deposits that were resulted from pyroclastics formed in an early violent explosion and then thrown into water and underwent rapid cooling, and developed with massive or graded beddings of poor sorting and several meters in thicknesses; (2) Neptunian density current deposit, the water-supported density current deposits formed by the subsequent collapse of the eruption column, which developed pumice lapilli with massive or weakly graded beddings shown by pumice size or content. Some examples are planar or low-angle cross-stratification. Crystals, pumiceous ash and dense clasts are few in this unit, and their sorting is moderate; (3) Neptunian suspension deposit, the pumice suspension deposition formed by the slow fallout of ash or pumice clasts, developed with laminar structure and covered early density current deposits (Fig. 5; Allen and Mcphie 2009).

\subsection{Oxidation index}

Oxidation index is generally applied to reflect the oxidation of volcanic rocks, which is represented by the content and ratio of $\mathrm{Fe}_{2} \mathrm{O}_{3}$ and $\mathrm{FeO}$ in volcanic rocks, and is defined as $\mathrm{Fe}_{2} \mathrm{O}_{3} / \mathrm{FeO}$ or $\mathrm{Fe}_{2} \mathrm{O}_{3} /\left(\mathrm{FeO}+\mathrm{Fe}_{2} \mathrm{O}_{3}\right)$ ratio (Qiu 1985). This ratio being larger than 1.5 means strongly oxidizing environment; being in between 1.0-1.5 means weakly oxidizing environment; being in between $0.8-1.0$ means weakly reducing environment; and being less than 0.8 means strongly reductive environment (Huang 1987). The oxidation analysis results of the Yingcheng Formation in the Xujiaweizi depression, Songliao Basin shows that all $\mathrm{Fe}_{2} \mathrm{O}_{3} / \mathrm{FeO}$ ratios of volcanic 
A

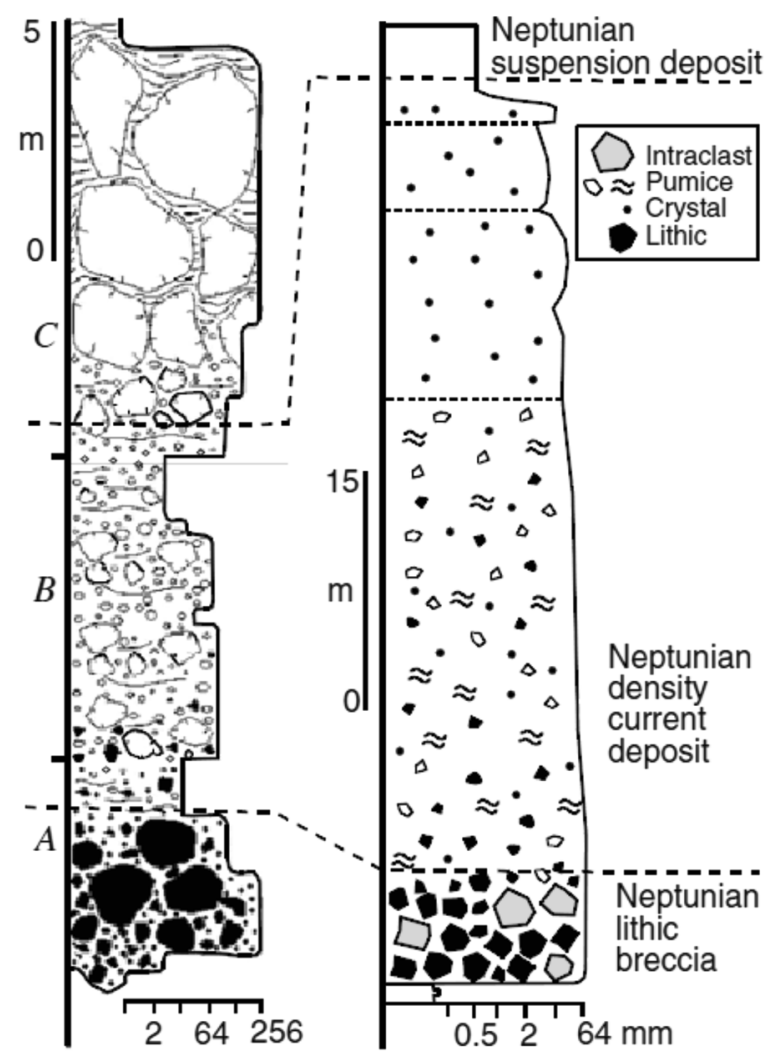

Fig. 5 Facies association model of submarine explosive eruption (from Allen and Mcphie 2009). Suspension deposit is composed of giant pumice and small ash (bimodal) in top deposits which resulted from pumice gradually wetting and weighting and subsidence occurring near volcanic vent after eruption when eruption ejected giant pumice; suspension deposit only contains small ash and is lack of pumice whose thickness obviously decreased if the deposit area is far away from volcanic vent or pumice ejected from eruption is limited

rocks are less than 0.8 , and some of them even less than 0.1 , which indicated that the volcanic eruption in this area was developed in a subaqueous strong reductive environment (Shan et al. 2013). $\mathrm{Fe}_{2} \mathrm{O}_{3} / \mathrm{FeO}$ ratios of the Late Jurassic rhyolitic quenching pyroclastic rocks and the Early Cretaceous basaltic quenching pyroclastic rocks in Fengning area, North China, are distributed between $0.34-0.64$ and $0.32-0.68$ with the average values of 0.485 and 0.490 , respectively; and, combined with the lithostratigraphic features of quenching pyroclastic rocks, the eruption of that time occurred in Fengning area is interpreted as hydrovolcanism (Xia 1993, 1999).

Notably, oxidation index is related to the environment as well as rock acidity $\left(\mathrm{SiO}_{2}\right.$ content) and the secondary change of volcanic rocks (Qiu 1985). Moreover, oxidation index usually increases with the increasing of rock acidity, the weathering time and the secondary change (Qiu 1985; He et al. 2017a). Therefore, rock acidity also must be considered when using oxidation index for environment identification. With full consideration of the influencing factors such as the eruption environment, magmatic properties, and weathering and burial diagenesis, the new eruption environment discrimination chart based on oxidation index has been established, and the coincidence rate of actual application results with other discriminators can reach $92.86 \%$ (He et al. 2017a, 2017b).

\section{Depositional environment records associated with volcanic eruption}

Volcanic eruption, characterized by the fast deposition rate and a short deposition process, belongs to one kind of event deposition. Thus, the sedimentary environment indicated by the associated normal deposition records volcanic depositional environment. Investigation of the depositional environment of those normal sediments directly underlying or overlying volcanic rocks is helpful to directly infer the environment information at the beginning and the end of volcanic eruption. It is relatively easy to reconstruct the deposition environment with such characteristics as the texture, structure, trace elements, and organic matter of normal sediments and their associated volcanic rocks. In this way, the entire outcrop and core data can be used to reconstruct the volcanic-depositional environment. For example, from the eruption products overlain by black shales and siltstones with substantial pyrite or laminar ash, it is reasonable to infer that the volcanic eruption in Mineral King Valley, California, USA, terminated in a deep-water reductive environment (Kokelaar and Busby 1992).

It is worth noting that the sediments associated with volcanic rocks indicate the depositional environment of the volcanic products, not necessarily the eruption environment. In addition, in the eruption process (especially in the explosive eruption process), the rapid and high-energy flow of volcanic materials may erode the underlying sediments, resulting in a partial loss of the underlying sediments. Therefore, it is necessary to observe whether there is obvious erosion or denudation on the contact surface between the sediments and volcanic materials when using the sedimentary records surrounding the volcanic rocks for identifying the volcanic eruption environment and volcanic eruption terminating environment. This method is extremely practical and highly reliable when the underlying sediment erosion caused by the volcanic eruption is of small scale, because the environment recognition based on sediments is straightforward. 


\section{Identification marks and their application} 5.1 Reliability and applicability of the identification marks The above paragraphs provide a large number of identification marks based on the features of volcanic eruption products and associated sediments (Table 1) for hydrovolcanism. However, not all identification marks are of the same reliability. To facilitate the convenient and effective application of these marks in identifying ancient volcanic eruptions, the reliability of different identification marks is discussed based on literature and experience (Table 2).
Different types of volcanic eruptions develop various lithofacies and lithofacies associations. Therefore, not every volcanic eruption has all or has the same identification marks. The most reliable ones for identifying the explosive eruption include quenching cracks, quenching textures, vesicles abundance, large-scale cross-beddings and the underlying depositional environment; the most reliable ones for identifying the effusive eruption include pillow structures, peperites, effusive lithofacies associations (including quenching structure) and the underlying depositional environment. The common identification

Table 2 Reliability and potential risks of the identification marks of hydrovolcanism

\begin{tabular}{|c|c|c|c|c|c|c|}
\hline \multicolumn{4}{|c|}{ Identification marks } & \multirow{2}{*}{$\begin{array}{l}\text { Direct } \\
\text { marks } \\
\text { No }\end{array}$} & \multirow{2}{*}{$\begin{array}{l}\text { Degree of } \\
\text { reliability } \\
* * * * *\end{array}$} & \multirow{3}{*}{$\begin{array}{l}\text { Potential risks } \\
\text { Destroyed by diagenesis } \\
\text { Destroyed by later thermodynamic contact } \\
\text { metamorphism }\end{array}$} \\
\hline \multirow{20}{*}{$\begin{array}{l}\text { Eruptive } \\
\text { products }\end{array}$} & \multirow[t]{11}{*}{ Microtextures } & \multicolumn{2}{|l|}{ Quenching cracks } & & & \\
\hline & & \multicolumn{2}{|c|}{ Bread-crusted structure } & No & $* * * *$ & \\
\hline & & \multicolumn{2}{|l|}{ Stepped fractures } & No & $* * * *$ & \\
\hline & & \multicolumn{2}{|c|}{ Cracks through particles } & No & $* *$ & \\
\hline & & \multicolumn{2}{|l|}{ Perlitic texture } & No & $* *$ & \\
\hline & & \multicolumn{2}{|c|}{ Grain size and its parameters } & No & $* * * *$ & \\
\hline & & \multicolumn{2}{|l|}{ Roundness } & No & ** & \\
\hline & & \multicolumn{2}{|l|}{ Quenching texture } & No & $* * * * *$ & \\
\hline & & \multicolumn{2}{|l|}{ Cementation type } & No & ** & \\
\hline & & \multicolumn{2}{|l|}{ Vesicularity } & Yes & $* * * * *$ & Only applied to explosive eruption identification \\
\hline & & \multicolumn{2}{|l|}{ Chilled margin } & No & ** & $\begin{array}{l}\text { Also developed in margins of ultra-shallow } \\
\text { intrusive rocks } \\
\text { Also developed in lava surface layer formed in } \\
\text { subaerial eruption }\end{array}$ \\
\hline & \multirow[t]{3}{*}{ Special structures } & \multicolumn{2}{|l|}{ Graded structures } & No & * & Also exist when volcanic materials were \\
\hline & & \multicolumn{2}{|c|}{ Large-scale cross-beddings } & No & $* * * * *$ & $\begin{array}{l}\text { transported } \\
\text { Turbidity deposits: Also could develop small-scale } \\
\text { graded beddings } \\
\text { Hydraulic jump: Also could develop antidune } \\
\text { beddings, water and wind beddings }\end{array}$ \\
\hline & & \multicolumn{2}{|l|}{ Pillow structures } & No & $* * * * *$ & $\begin{array}{l}\text { Only applied to lava in effusive facies } \\
\text { Also formed when the subaerial magma flows } \\
\text { into river } \\
\text { Note to distinguish from non-radial joints and } \\
\text { vacant spherical weathering }\end{array}$ \\
\hline & \multirow[t]{5}{*}{$\begin{array}{l}\text { Lithofacies and facies } \\
\text { sequences }\end{array}$} & \multirow[t]{3}{*}{ Lithofacies } & Perlite & No & ** & $\begin{array}{l}\text { Also formed in intrusive body under water-rich } \\
\text { environment }\end{array}$ \\
\hline & & & Peperite & No & $* * * * *$ & \\
\hline & & & Spilite & No & $* * *$ & Origin is controversial \\
\hline & & \multirow[t]{2}{*}{ Facies sequences } & Effusive & No & $* * * * *$ & \\
\hline & & & Explosive & No & $* * * *$ & Hard to be applied alone \\
\hline & \multicolumn{3}{|l|}{ Oxidation index } & No & $* * * *$ & $\begin{array}{l}\text { Magma content can affect the oxidation index } \\
\text { Secondary changes of volcanic rocks such as } \\
\text { the late weathering } \\
\text { Note the oxidation in the test experiment }\end{array}$ \\
\hline \multirow{2}{*}{$\begin{array}{l}\text { Associated } \\
\text { environment }\end{array}$} & \multicolumn{3}{|c|}{ Overlying sedimentary environment } & No & $* * * * *$ & The following two conditions need to be cautiously \\
\hline & \multicolumn{3}{|c|}{ Underlying sedimentary environment } & No & $* * * *$ & $\begin{array}{l}\text { applied: (1) Large-scale scouring in the bottom and } \\
\text { depositional breaks occur; (2) Being exposed after } \\
\text { hydrovolcanism, weathering and/or erosion }\end{array}$ \\
\hline
\end{tabular}


marks of these two eruption types consist of the underlying depositional environment (background factors), quenching structure and its products which were resulted from the encountering of hot volcanic materials into the cooler water.

Among the most reliable marks, maybe any individual one can solely confirm the volcanic eruption environment. However, for the relatively lower reliability marks, mutual verification using multiple marks is needed to ensure the accuracy of environment identification. The lower reliability of marks means that more solid evidence should be synthetically considered.

\subsection{Direct or indirect identification marks of eruption environment}

In the above discussion regarding various identification marks, it is emphasized that the identification marks from the characteristics of the volcanic products mostly reflect the depositional environmental information of the eruption products. Of all the identification marks discussed here, only vesicles content of pyroclasts ejected from an explosive eruption is directly related to the eruption environment, which can be used as the direct evidence for identifying the eruption environment (Table 1, Table 2). Other identification marks do not directly reflect the eruption environment but the depositional environment instead. The following conditions should be matched first if the aforementioned indirect marks are also used to identify the eruption environment: (1) eruption position (the crater) is flat and very close to depositional area; (2) depositional area is located in deep water in large-scale basins and meanwhile the volcanic materials do not belong to the reworked sediments of early eruptive products. Otherwise, it is difficult to ensure that the depositional environment can reflect or represent the eruption environment.

Furthermore, the identification marks of eruption products discussed here are mainly developed in the process of condensed diagenesis of magma and pyroclasts, mainly reflecting depositional environment. Compared with explosive eruptions, the underwater accumulation of subaerial eruption and/or of subaqueous eruption of effusive eruptions are easy to distinguish. For the explosive eruptions such as pyroclastic surge and pyroclastic flow, the combination of transportation-deposition medium, diagenetic features and environment of associated normal sediments is indispensable for distinguishing the underwater accumulation developed in subaerial or subaqueous eruptions.

\section{Influences of eruption environment on volcanic reservoirs}

Petroleum exploration reveals that the prediction of volcanic reservoirs is the key to exploring high-quality reservoirs (Wang et al. 2003a; Zou et al. 2008; Xian et al. 2013). Previous investigations demonstrate that the property of volcanic reservoirs is mainly controlled by volcanism, diagenesis, weathering, and tectonic activities (Chen et al. 2003; Wang et al. 2003b; Dong et al. 2012; Xian et al. 2013).

Due to the lack of effective identification marks of a hydrovolcanism, it is generally assumed that subaqueous eruption is similar to subaerial eruption (Head and Wilson 2003), ignoring the impact of water on volcanic reservoir development. Recently, it has been suggested that the eruption environment has substantial effects on the quality of volcanic reservoirs, based on the case studies of volcanic reservoirs in the Junggar Basin (Dong et al. 2012; Zhu et al. 2012; Xian et al. 2013).

The reservoir space of volcanic reservoirs is composed of primary porosity, secondary porosity and fractures. The differences in explosive degree, quenching, vesicles distribution and cementation between subaqueous eruption and subaerial eruption will result in the differences in primary-secondary porosity and fractures of volcanic reservoirs in different eruption/depositional environment.

\subsection{Eruption environment influence on the development of primary porosity and fractures}

The primary pores in volcanic rocks consist of vesicles, intergranular pores, intracrystal pores, and primary fractures including autobrecciated or cryptoexplosive fractures, and chilling contraction joints (Zou 2013).

The content of vesicles in volcanic rocks mainly depends on the viscosity, volatile components, condensation and consolidation environment of magma, water depth and development of "globoid" with inner cavity (Head and Wilson 2003). On the one hand, in the process of hydrovolcanism, the hot magma is submerged into the quenching media-water, which is beneficial to seal most vesicles into pyroclasts or plastic fragments. On the other hand, the increase of water depth and static pressure will inhibit the exsolution of volatile components in hydrovolcanism and reduce the primary porosity which is obvious in pillow basalt of deep-sea submarine eruption. The hydraulic pressure impedes the escape of volatiles and makes vesicle development of volcanic rocks in a hydrovolcanism less than that in a subaerial eruption, the latter of which, having 25\% vesicle content, is favorable for hydrocarbon accumulation (Run et al. 1996). Thus, the vesicle development depends on consolidation environment and water depth (pressure) in addition to volatile content and magma properties.

Furthermore, magma-water interaction and quenching caused by hydrovolcanism help to develop plenty of quenching pyroclastic rocks and quenching breccia lava, and increase intergranular and intercrystal pores of 
volcanic rocks. In addition, the condensation and contraction promote the formation of contraction joints and explosive fractures, such as quenching cracks, bread-crusted structure, stepped fractures, perlitic texture, porphyrocrystic cracks and arc-shaped fissures.

Previous studies showed that rock constituents of the Wucaiwan depression and the Shixi depression in the Junggar Basin were similar but the reservoir quality of these two depressions was obviously different; the average porosity of the former is $8.14 \%$, while that of the latter is $14.77 \%$. This difference is mainly derived from their different eruption environments. The volcanic eruption of the Wucaiwan depression belongs to subaerial eruption without water involving, whereas the volcanic eruption of the Shixi depression is a hydrovolcanism (Zou 2013). The volcanic breccia in the Jiyang depression is characterized by dense vesicles with diameter of $0.01 \mathrm{~mm}$, caused by rapid cooling of magma as it interacted with water generating vitreous materials without vesicles aggregating and overflowing. The basalt of Well Bin674 is formed by magma overflowing into water and quenching with water, accompanied by generating vesicles among breccia and deformational vesicles between breccia (Xie et al. 1998).

The irregular vesicles (Fig. 6a) of the products of the $\sim 27$ ka phreatomagmatic eruption in Oruanui Volcano, New Zealand were very similar to these cavities (Fig. 6b) of the physical simulation experiment, which were generated from interactions between magma and the mixture composed of liquid water and solid ice in $18 \pm 2{ }^{\circ} \mathrm{C}$ (Experiment Mix-2; Van Eaton et al. 2012). It is particularly noteworthy that the products of the simulation experiment regarding magma and solid ice contain large number of vesicles and cavities with diameters of 2-10 cm (Fig. 6c), resembling those cavities developed in subglacial volcano lava in British Columbia (Fig. 6d), Canadian (Edwards et al. 2013). In the core of the Fengcheng Formation of Well Xia201 in the Junggar Basin, vesicles and cavities were widely developed in global grains (Fig. 6e) and had similar characteristics to the two aforementioned eruption products, part of which were filled with authigenetic quartz (Fig. 6f).

The above discussions showed that the magma volatiles exsolution, magma-water interaction and quenching are related to the water depth of the eruptive vent. If the eruptive vent is deep, the huge hydrostatic pressure will suppress volatiles exsolution and explosive eruption. Research on the critical pressure or depth of inhibiting explosive eruption has long been a focus. The water depth of most explosive eruptions was less than $200 \mathrm{~m}$, which is illustrated by case studies (i.e., Cas et al. 2001). The theoretical calculation shows that the critical depth for the exsolution of the $\mathrm{CO}_{2}$-dominated component of magmatic volatiles, is approximately $700 \mathrm{~m}$, and its corresponding critical pressure is $7.38 \mathrm{Mpa}$ (Head and Wilson 2003), which is basically consistent with the early estimation that the water depth of an explosive eruption is less than 500-1000 $\mathrm{m}$ (Mcbirney 1963). In other words, the exsolution of magmatic volatiles will not result in explosive eruption in deep water area below $700 \mathrm{~m}$. However, this has been disproved by recent observations. Some experiments and theoretical investigations even demonstrate that explosive eruptions can possibly occur under $4000 \mathrm{~m}$ (Wohletz 2003), because of the correlated magma-water interactions which could generate a mass of vapor and provide energy for volcanic explosion (Head and Wilson 2003).

\subsection{Eruption environment influence on the development of secondary pores}

Similarly with sandstone, the secondary porosity in volcanic rocks is usually resulted from the dissolution of unstable granules such as feldspars and rock fragments (Shanmugam 1985). Secondary pores in volcanic rocks commonly include devitrified pores, various dissolved pores (feldspar, carbonate and volcanic ash), weathered and leached caves, etc. Because of the large amount of unstable vitreous minerals in hydrovolcanism products, pyroclastic sediments can devitrify in shallow burial and low temperature conditions, which contributes to the development of devitrified pores. Moreover, the improvement of hydrovolcanism on the development of primary pores and fractures, especially in shallow water, may increase the matrix pores of volcanic rocks, which provides space for the growth of early cements such as chlorite, zeolite and calcite, and late fluid activity and material interchange, and further promotes the longterm development of secondary dissolved pores. Therefore, the influence of the eruption environment on the primary porosity and fractures may also affect the development of secondary pores in the diagenetic stage (Mathisen and Mcpherson 1991).

\section{Conclusions}

Models of volcanic eruptions and characteristics of their products are not only controlled by the properties of the magma itself, but also by the eruption environments. The great differences between two eruption media, air and water, in such viscosity, density and thermal conductivity lead to the particularity of hydrovolcanism processes and products. Also, the characteristics of products can be used to identify the eruption environment.

The structure and texture of the underlying sedimentary rocks (sediments) and volcanic rocks (products) are applied to discern the ancient volcanic eruption environments. Sedimentary rocks associated with the development of volcanic rocks, especially 

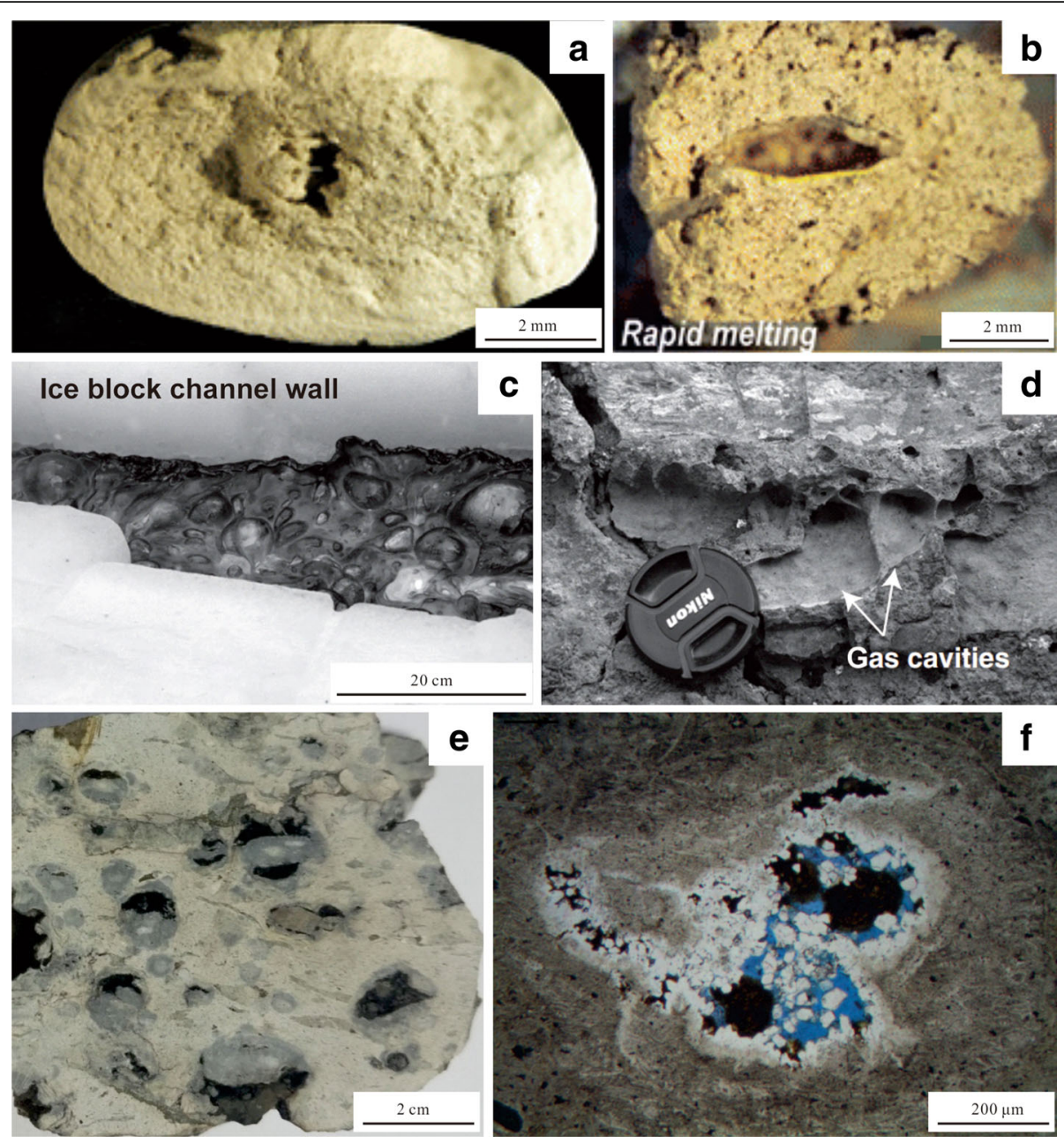

Fig. 6 Pores of hydrovolcanism products. a The $\sim 27$ ka phreatomagmatic eruption products in Oruanui Volcano, New Zealand, showing the inner irregular vesicles (Van Eaton et al. 2012); b Physical simulation experiment products formed from the interaction between the magma and the liquid-solid-water mixture in the $18 \pm 2{ }^{\circ} \mathrm{C}$ condition (Experiment Mix-2), showing the inner cavities (Van Eaton et al. 2012); c Products generated from the magma-ice interaction, showing plenty of vesicles in lava surface (Edwards et al. 2013); d Mount of cavities developed in subglacial volcano lava in British Columbia, Canadian (Edwards et al. 2013); e Core photo of the first Member of the Fengcheng Formation $\left(P_{1} f_{1}, 4832.00 \mathrm{~m}\right)$ in Well Xia201 in the Junggar Basin, showing pores developed in a lot of particles; $\mathbf{f}$ Microscopic photo of the Fig. 6e, particles developed large pores and parts of them were filled with authigenetic quartz

those beneath volcanic rocks, provide direct evidence for the identification of the volcanic eruption environment. In addition, the microtexture, structure, lithofacies successions and geochemical parameters of the eruption products can indirectly indicate the volcanic eruption environment. The reliability and applicability of various identification marks are different. For explosive eruption, cracks, quenching structures, vesicles abundance, large-scale cross-beddings and the underlying depositional environment are the most reliable; as for effusive eruption, pillow structures, peperites, lithofacies associations and the underlying depositional environment are the most reliable. To elevate the identification accuracy, comprehensive consideration on multiple evidence types is essential. The lower reliability of marks means that more types of evidence is needed.

The eruption style, affected by eruption environments, and magma properties decide structures of eruption products, and the development types, degree and disciplines of the primary reservoir space. Magma -water interaction of hydrovolcanism in shallow water helps to increase the amount and connectivity of matrix pores, and form fractures. Therefore, the influence of eruption environment on the quality of volcanic reservoir should be considered to elevate the 


\section{accuracy of volcanic reservoir prediction in volcanic reservoir assessment.}

\section{Acknowledgements}

This work was jointly supported by the National Natural Science Foundation of China (Grants No. 41172104 and No. 41372117), and the National Science and Technology Major Project (Grants No. 2017ZX05009-002 and No. 2016ZX05026-007). Authors are grateful to the reviewers and editors for their valuable comments and suggestions, especially Prof. Zhi-Da Bai of CUGB, for improving the quality of the original manuscript.

\section{Authors' contributions}

All authors read and approved the final manuscript.

\section{Competing interests}

The authors declare that they have no competing interests.

\section{Publisher's Note}

Springer Nature remains neutral with regard to jurisdictional claims in published maps and institutional affiliations.

\section{Received: 8 December 2017 Accepted: 13 April 2018}

Published online: 26 September 2018

\section{References}

Allen, S.R., and J. Mcphie. 2009. Products of neptunian eruptions. Geology 37 (7): 639-642.

Bai, Z.D., S.P. Sun, D.B. Xu, and Y.S. Liu. 2004. An important kind of pyroclastic rock - Peperite. Earth Science Frontiers 11 (3): 134 (in Chinese with English Abstract).

Belousov, A., and M. Belousova. 2001. Eruptive process, effects and deposits of the 1996 and the ancient basaltic phreatomagmatic eruptions in Karymskoye lake, Kamchatka, Russia. In Volcaniclastic sedimentation in lacustrine settings, ed. J.D.L. White and N.R. Riggs, 35-60. Oxford: Blackwell Sciences.

Büttner, R., P. Dellino, L. La Volpe, V. Lorenz, and B. Zimanowski. 2002. Thermohydraulic explosions in phreatomagmatic eruptions as evidenced by the comparison between pyroclasts and products from molten fuel coolant interaction experiments. Journal of Geophysical Research: Solid Earth 107 (B11): 2277. https://doi.org/10.1029/2001JB000511.

Büttner, R., P. Dellino, and B. Zimanowski. 1999. Identifying magma-water interaction from the surface features of ash particles. Nature 401 (6754): 688-690.

Carey, S. 2000. Volcaniclastic sedimentation around island arcs, 627-642. New York: Academic Press.

Caroff, M., M. Vidal, A. Benard, and J.R. Darboux. 2009. A late-Ordovician phreatomagmatic complex in marine soft-substrate environment: The Crozon volcanic system, Armorican massif (France). Journal of Volcanology and Geothermal Research 184 (3-4): 351-366.

Cas, R. A. F., C. J. Edgar, R. L. Allen, B. A. Clifford, S. Bull, F. Giordano, and A. B. Wright. 2001. "Influence of magmatism and tectonics on sedimentation in an extensional lake basin: The upper Devonian Bunga beds, Boyd volcanic complex, southeastern Australia." In: White, J.D.L. and Riggs, N.R. Volcaniclastic sedimentation in lacustrine settings. Special publication number 30 of the International Association of Sedimentologists. Pp.83-108.

Cas, R.A.F., and G. Giordano. 2014. Submarine volcanism: A review of the constraints, processes and products, and relevance to the Cabo de Gata volcanic succession. Italian Journal of Geosciences 133 (3): 362-377.

Cas, R.A.F., and J.V. Wright. 1987. Volcanic successions, modern and ancient: A geological approach to processes, products, and succession. London: Unwin Hyman.

Chen, Q.C., D.Y. Zhu, W.X. Hu, and X.W. Cao. 2003. Classification and characteristics of oil and gas reservoir beds of volcanic rocks. Geological Review 49 (03): 286-291 (in Chinese with English Abstract).

Chen, S., Z.J. Guo, Pe-Piper Georgia, and B.B. Zhu. 2013. Late Paleozoic peperites in west Junggar, China, and how they constrain regional tectonic and palaeoenvironmental setting. Gondwana Research 23 (2): 666-681.

De Rita, D., G. Giordano, A. Esposito, M. Fabbri, and S. Rodani. 2002. Large volume phreatomagmatic ignimbrites from the Colli Albani volcano (middle Pleistocene, Italy). Journal of Volcanology and Geothermal Research 118 (1-2): 77-98.
Dellino, P., R. Isaia, and L. La Volpe. 2001. Statistical analysis of textural data from complex pyroclastic sequences: Implications for fragmentation processes of the Agnano-Monte spina tephra, Phlegraean fields, southern Italy. Bulletin of Volcanology 63 (2): 443-461.

Dong, G.D., Q. Zhang, X.M. Zhu, B.Z. Xian, S.F. Zhu, H.P. Niu, and Q.Y. Chen. 2012. Current status and problems of volcanic reservoir study: An example from the lower Permian volcanic rocks in Ke-Xia area of Junggar Basin. Oil \& Gas Geology 33 (04): 511-519 (in Chinese with English Abstract).

Dziak, R.P., D.R. Bohnenstiehl, E.T. Baker, H. Matsumoto, A.J. Caplan, R.W. Embley, S.G. Merle, S.L. Walker, T.K. Lau, and W.W. Chadwick. 2015. Long-term explosive degassing and debris flow activity at West Mata submarine volcano. Geophysical Research Letters 42 (5): 1480-1487.

Edwards, B.R., J. Karson, R. Wysocki, E.B.I. Lev, and U. Kueppers. 2013. Insights on lava-ice/snow interactions from large-scale basaltic melt experiments. Geology 41 (8): 851-854.

Fisher, R.V., H.U. Schmincke, and P. Van Bogaard. 1983. Origin and emplacement of a pyroclastic flow and surge unit at Laacher see, Germany. Journal of Volcanology and Geothermal Research 17 (1-4): 375-392.

Gifkins, C.C., J. Mcphie, and R.L. Allen. 2002. Pumiceous rhyolitic peperite in ancient submarine volcanic successions. Journal of Volcanology and Geothermal Research 114 (1-2): 181-203.

Hanson, R.E., and T.J. Wilson. 1993. Large-scale rhyolite peperites (Jurassic, southern Chile). Journal of Volcanology and Geothermal Research 54 (3-4): 247-264.

He, Y.X., B.Z. Xian, H.P. Niu, and J.P. Liu. 2017b. Effects of paleogeographic environment on volcano eruption style: Example from the Fengcheng formation in eastern Mahu sag, Junggar Basin. Journal of Palaeogeography (Chinese Edition) 20 (2): 246-262 (in Chinese with English Abstract).

He, Y.X., B.Z. Xian, H.P. Niu, X.L. Zhang, and J.N. Shen. 2017a. Discrimination of volcanic eruption environment using oxidation index: A case study of lower Permian volcanic rocks in northwestern margin of Junggar basin. Geological Journal of China Universities 23 (4): 737-749 (in Chinese with English Abstract).

Head, J.W., and L. Wilson. 2003. Deep submarine pyroclastic eruptions: Theory and predicted landforms and deposits. Journal of Volcanology and Geothermal Research 121 (3-4): 155-193.

Huang, J.X. 1987. Differentiation of oxidation-reduction sedimentary environment of the Xiamen harbour. Journal of Oceanography In Taiwan Strait 06 (01): 27-32 (in Chinese with English Abstract).

Kokelaar, P., and C. Busby. 1992. Subaqueous explosive eruption and welding of pyroclastic deposits. Science 257 (5067): 196-201.

Kuang, L.C., H.T. Lu, J.J. Xue, X.M. Zhu, and D.J. Li. 2008. Characteristics of volcanic reservoirs in Jiamuhe formation of Permian in the 5th and 8th districts, northwestern margin of Junggar Basin. Geological Journal of China Universities 14 (2): 164-171 (in Chinese with English Abstract).

Liu, J.S. 1995. Characteristics of the submarine volcanism and its volcanic rocks Geological Exploration for Non-Ferrous Meltals 4 (1): 35-37 (in Chinese with English Abstract).

Liu, J.S., S.X. He, and X.D. Xiao. 1993. Geochemistry and geotectonic setting of Wanyan volcanic-intrusive complex in Hunan, South China. Journal of Central-South Institute of Mining and Metallurgy 24 (2): 149-155 (in Chinese with English Abstract).

Liu, X., and X.K. Wang. 1987. Discovery of the volcanic base-surge deposits in Dalongwan, Huinan County, Jilin Province. Geological Review 33 (6): 577-582 (in Chinese with English Abstract).

Liu, ZJ., Q.Y. Miao, X. Liu, and R. Liu. 2008. Geological features and significance of base surge deposits. Oil \& Gas Geology 29 (1): 11-18 (in Chinese with English Abstract).

Manville, V., K. Németh, and K. Kano. 2009. Source to sink: A review of three decades of progress in the understanding of volcaniclastic processes, deposits, and hazards. Sedimentary Geology 220: 136-161.

Mathisen, M.E., and J.G. Mcpherson. 1991. Volcaniclastic deposits: Implications for hydrocarbon exploration. In Sedimentation in volcanic settings. Society of Economic Paleontologists and Mineralogists Special Publication, ed. G.A. Smith and R.V. Fisher, 27-36.

Mcbirney, A.R. 1963. Factors governing the nature of submarine volcanism. Bulletin of Volcanology 26: 443-453.

McClintock, M.K., and J.D.L. White. 2002. Granulation of weak rock as a precursor to peperite formation: Coal peperite, Coombs Hills, Antarctica. Journal of Volcanology and Geothermal Research 114 (1-2): 205-217.

Nemeth, K., and C.M. White. 2009. Intra-vent peperites related to the phreatomagmatic 71 gulch volcano, western Snake River plain volcanic field Idaho (USA). Journal of Volcanology and Geothermal Research 183 (1-2): 30-41. 
Pardo, N., D.R. Avellan, J.L. Macias, T. Scolamacchia, and D. Rodriguez. 2008. The similar to 1245 yr BP Asososca maar: New advances on recent volcanic stratigraphy of Managua (Nicaragua) and hazard implications. Journal of Volcanology and Geothermal Research 176 (4): 493-512.

Petrinovic, I.A., and F. Colombo Piñol. 2006. Phreatomagmatic and phreatic eruptions in locally extensive settings of southern Central Andes: The

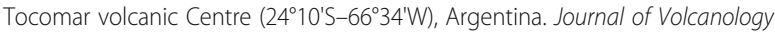
and Geothermal Research 158 (1-2): 37-50.

Qiu, J.X. 1985. The adjustments of $\mathrm{Fe}_{2} \mathrm{O}_{3}$ and $\mathrm{FeO}$ in volcanic rocks. Geological Science and Technology Information 4 (2): 32-39 (in Chinese with English Abstract).

Run, C.D., H.L. Yu, F.Q. Yu, and D.F. Wang. 1996. Pores development and reservoir properties of volcanic rocks in Jianghan basin. Journal of Jianghan Petroleum Institute 18 (2): 1-6 (in Chinese with English Abstract).

Sang, L.K., and C.Q. Ma. 2012. Petrology. Beijing: Geological Publishing House (in Chinese).

Seghedi, I. 2011. Permian rhyolitic volcanism, changing from subaqueous to subaerial in post-Variscan intra-continental Sirinia Basin (SW Romania-Eastern Europe). Journal of Volcanology and Geothermal Research 201 (1-4): 312-324.

Shan, X.L., J.Y. Li, S.M. Chen, Q.C. Ran, G.B. Chen, and C. Liu. 2013. Subaquatic volcanic eruptions in continental facies and their influence on high quality source rocks shown by the volcanic rocks of a faulted depression in Northeast China. Science China Earth Sciences 56 (11): 1926-1933.

Shan, X.L., Q.D. Liu, L.J. Ren, and Y.T. Zhao. 2007. Geological characteristics and genesis of perlite in the lower cretaceous Yingcheng formation in the Santai area of the Songliao Basin. Journal of Jilin University-Earth Science Edition 37 (6): 1146-1151 (in Chinese with English Abstract).

Shanmugam, G. 1985. Significance of secondary porosity in interpreting sandstone composition. AAPG Bulletin 69 (3): 378-384.

Shanmugam, G. 2017. The fallacy of interpreting SSDS with different types of breccias as seismites amid the multifarious origins of earthquakes: Implications. Journal of Palaeogeography 6 (1): 12-44.

Simpson, K., and J. McPhie. 2001. Fluidal-clast breccia generated by submarine fire fountaining, Trooper Creek formation, Queensland, Australia. Journal of Volcanology and Geothermal Research 109 (4): 339-355.

Skilling, I.P., J.D.L. White, and J. McPhie. 2002. Peperite: A review of magmasediment mingling. Journal of Volcanology and Geothermal Research 114: 1-2): $1-17$.

Soriano, C., G. Giordano, R. Cas, N. Riggs, and M. Porreca. 2013. Facies architecture, emplacement mechanisms and eruption style of thesubmarine andesite El Barronal complex, Cabo de Gata, SE Spain. Journal of Volcanology and Geothermal Research 264: 210-222.

Stix, J. 1991. Subaqueous, intermediate to silicic-composition explosive volcanism: A review. Earth Science Reviews 31: 21-53.

Sun, Q., and Q.C. Fan. 2005. Study progress on volcanic phreatomagmatic eruption. Acta Petrologica Sinica 21 (6): 1709-1718 (in Chinese with English Abstract).

Valentine, G. A., and R. V. Fisher. 1999. "Pyroclastic surges and blasts." In: H. Sigurdsson, B. Houghton, H. Rymer, J. Stix, and S. McNutt. Encyclopedia of Volcanoes. Academic Press, pp. 571-80.

Van Eaton, A.R., J.D. Muirhead, C.J.N. Wilson, and C. Cimarelli. 2012. Growth of volcanic ash aggregates in the presence of liquid water and ice: An experimental approach. Bulletin of Volcanology 74 (9): 1963-1984.

Walker, G.P.L. 1971. Grain-size characteristics of pyroclastic deposits. The Journal of Geology 79 (6): 696-714

Wang, L., W.H. Li, T. Lin, H. Liang, and H.G. Gou. 2010. A comparative analysis of submarine eruptive and subaerial eruptive volcaniclastic reservoir on characteristics of reservoir and reservoir forming dominated factors: Taking carboniferous volcaniclastic reservoir in Santanghu Basin as example. Chinese Journal of Geology 45 (4): 1088-1097 (in Chinese with English Abstract).

Wang, P.J., S.M. Chen, W.S. Liu, X.L. Shan, R.H. Cheng, Y. Zhang, H.B. Wu, and J.S Qi. 2003a. Relationship between volcanic facies and volcanic reservoirs in Songliao Basin. Oil \& Gas Geology 24 (1): 18-23 (in Chinese with English Abstract).

Wang, P.J., Y.L. Chi, W.S. Liu, R.H. Cheng, X.L. Shan, and Y.G. Ren. 2003b. Volcanic facies of the Songliao basin: Classification, charcteristics and reservoir significance. Journal of Jilin University-Earth Science Edition 33 (4): 449-456 (in Chinese with English Abstract).

White, J.D.L., C.I. Schipper, and K. Kano. 2015. Chapter 31 - Submarine Explosive Eruptions. In The encyclopedia of volcanoes, ed. H. Sigurdsson, B. Houghton, H. Rymer, J. Stix, and S. McNutt, 2nd ed., 553-569. Amsterdam: Elsevier.
White, J.D.L., J.L. Smellie, and D.A. Clague. 2003. Introduction: A deductive outline and topical overview of subaqueous explosive volcanism. Geophysical Monograph 140: 1-23.

Wohletz, K., B. Zimanowski, and R. Büttner. 2013. Magma-water interactions. In Modeling volcanic processes: The physics and mathematics of volcanism, ed. S. A. Fagents, T.K.P. Gregg, and R.M.C. Lopes, 230-257. Cambridge University Press.

Wohletz, K.H. 2003. Water/magma interaction: Physical considerations for the deep submarine environment. Geophysical Monograph 140: 25-50.

Xia, G.L. 1993. Features and genesis of terrestrial basaltic vitroclastic rocks in northern Hebei. Regional Geology of China 12 (3): 223-228 (in Chinese with English Abstract).

Xia, G.L. 1999. Discovery and geological characteristics of rhyolitic vitroclastic rocks in northern Hebei. Regional Geology of China 18 (2): 127-132 (in Chinese with English Abstract).

Xian, B.Z., H.P. Niu, G.D. Dong, S.F. Zhu, and S.Q. An. 2013. Early Permian volcanic lithology, lithofacies and their relations to reservoir in northwestern margin of the Junggar Basin. Geological Journal of China Universities 19 (1): 46-55 (in Chinese with English Abstract).

Xie, Z.H., B.J. Liu, Y. Xia, P. Wang, and N. Liu. 1998. Lithofacies, reservoir characteristics and genesis of tertiary volcanic rocks in Jiyang depression. Multiple Oil-Gas Field 4: 62-64 (in Chinese).

Xu, D.B., Z.D. Bai, B.L. Zhang, and H.J. Hong. 2005. Characteristic and genetic mechanism of pyroclastic base-surge deposits of volcanic swarm in Longgang area, Jilin Province. Acta Sedimentologica Sinica 23 (01): 60-66 (in Chinese with English Abstract).

Yang, R.X. 2000. Spilite-keratophyre sequence and its genesis. Mineral Resources and Geology 14 (02): 109-113 (in Chinese with English Abstract).

Yu, C.M., J.P. Zheng, Y. Tang, Z. Yang, and X.F. Qi. 2004. Reservoir properties and effect factors on volcanic rocks of basement beneath Wucaiwan depression, Junggar basin. Earth Science-Journal of China University of Geosciences 29 (03): 303-308 (in Chinese with English Abstract).

Yu, H.M. 2012. Microstructural study on volcanic products and its geological implications. Beijing: Institute of Geology, China Earthquake Administration (in (hinese).

Yu, H.M., J.D. Xu, and C.Y. Lin. 2008. Study on the characteristics of quaternary volcanic pyroclasts from Nanlongwan volcano, Longgang volcanic cluster, Jilin Province. Acta Petrologica Sinica 24 (11): 2621-2630 (in Chinese with English Abstract)

Yu, H.M., J.D. Xu, and C.Y. Lin. 2011. Morphological characterization and terminal velocity of pumice particles erupted during the millennium eruption of Changbaishan Tianchi volcano, China. Seismology and Geology 33 (2): 440-451 (in Chinese with English Abstract).

Zhang, Y., P. Shu, P.J. Wang, C.Q. Zheng, and X.L. Shan. 2007. Comparison between subaerial and subaqueous volcanic rocks and the reservoir significance - Taking Yingcheng Formation in Songliao basin as example. Journal of Jilin University-Earth Science Edition 37 (6): 1259-1265 (in Chinese with English Abstract).

Zhao, Z.H. Z.J. Guo, B.F. Han, and Y. Wang. 2006. The geochemical characteristics and tectonic-magmatic implications of the latest-Paleozoic volcanic rocks from Santanghu Basin, eastern Xinjiang, Northwest China. Acta Petrologica Sinica 22 (1): 199-214 (in Chinese with English Abstract).

Zhu, S.F., X.M. Zhu, J.S. Liu, Y. Yao, B.Z. Xian, H.P. Niu, and Z.Y. Zhao. 2012. Genesis and hydrocarbon significance of vesicular welded tuffs: A case study from the Fengcheng formation, Wu-Xia area, Junggar Basin, NW China. Petroleum Exploration and Development 39 (2): 173-183.

Zou, C.N. 2013. Unconventional petroleum geology, 192-204. Beijing: Geological Publishing House.

Zou, C.N., W.Z. Zhao, C.Z. Jia, R.K. Zhu, G.Y. Zhang, X. Zhao, and X.J. Yuan. 2008 Formation and distribution of volcanic hydrocarbon reservoirs in sedimentary basins of China. Petroleum Exploration and Development 35 (3): 257-271 (in Chinese with English Abstract). 